\title{
Spot and Derivative Contract Prices: Articulation of Relationships of Cardamom through ARDL Method
}

\author{
Sachin Kumar, Yash Pal Taneja, Nishi Bala
}

\begin{abstract}
India is known as land of spices and boast of a long history in spices trading. Cardamom derivative contract is listed for trading on Multi commodity Exchange in India. This paper endeavors to find out relationship between spot and derivative contract of cardamom. The relationship is also tested between derivative price of cardamom and spot price. Two period derivative contracts, near month contract and next contract of cardamom are used for the study. Long run relationship is examined through ARDL Bounds test. ECM is applied to find out short term relationship and speed of adjustment towards long run. Long run relationship was found between spot and derivative as well as between derivative and spot. Long run relationship was established in both period contracts. Short run relationship was also established and speed of adjustment is higher in near month contract.
\end{abstract}

Index Terms: Derivative contract, Spot contract, ARDL, ECM, Cointegration

\section{INTRODUCTION}

India is known as land of spices and boast of a long history in spices trading. India has diverse soil and climate which provides the opportunity to cultivate a variety of spice crops. Spices are low volume and high value crops. Spices plays a unique role in economy of India, as this is labour intensive industry so provides great opportunities of employment in rural India. Most of these spices are produced in southern of parts of India and exported out of India The major spices produced in India are Cardamom, Chilli, Pepper, Turmeric, cumin, Ginger, Coriander, Fenugreek, Garlic etc. Cardamom is one of the valuable spices which is exported out of India. In year 2016-17, 3850 Tons of cardamom valuing 421.5 crores was exported from India. In year 2017-18 there is substantial increase in export of cardamom as 5680 Tons of cardamom was exported from India valuing Rs.609.08 crores as per report of Ministry of Commerce and industry. To ensure transparency and better price for cardamom to the growers cardamom is listed in derivative market of Multi commodity Exchange in India (MCX). Derivatives commodity markets are primarily used as a tool by farmers and participants to understand the trend of the market on price front on the basis of which an informed decision on whether to hold the crop or to sell the crop. Efficient commodity market, the derivatives price is considered to be an unbiased predictor of the spot price at expiry of contract and the current derivatives price

\footnotetext{
Revised Manuscript Received on October 25, 2019

Lourden Selvamani, Research Scholar, Department of International Business, Pondicherry University, Pondicherry, India.

P.G . Arul, Professor, Department of International Business, Pondicherry
} University, Pondicherry, India. should be match to the spot price on maturity of derivative (Kellard et al.,1999; Haigh, 2000). Market efficiency implies cointegration between spot market and derivative market as both the markets are dependent on same factors. So spot and derivative prices should not drift from each other (Beck S 1994). So it is important to find out relationship between spot and derivative market.

\section{REVIEW OF LITERATURE}

Wiese and Lake (1978) studied the price discovery between spot prices and derivative prices. The significance of their study depends upon the convergence between spot market and derivative market. Kawaller et al (1987) revealed that movement in index derivative leads to movement in spot market and relationship exist between spot and derivative. Stoll and Whaley (1990) found that S\&P500 derivatives price lead in price discovery of spot price. Schwarz and Szakmary (1994) studied the inter relationship between the spot and derivatives market. He used data from NYMEX in the petroleum sector and concluded that petroleum derivatives and spot markets are co integrated and the derivatives market overtakes the spot market. Beck (1994) examined the long run and short run market efficiency, with the help of cointegration and ECM, in five US commodity derivatives markets for 8 and 24 weeks time span. Garbade and Sibler (1983) and later on Engle and Granger (1987), examined price discovery process through co integration technique. Silvapulle and Moosa (1999) examined the relationship between the spot and crude oil derivative contract prices. Daily crude oil data was colleected from NYMEX. Linear causality test results depict that derivative prices lead spot prices, but nonlinear causality testing shows a bi-directional casual relationship. Yang and Leatham (1999) examine price discovery process in derivative contract of wheat through used forecast error variance decomposition found that future play a leading role. Moosa (2002) applied Garbade and Silber (1983) model to find out role of derivative in price discovery along with risk transfer using data of crude oil. Daily price data of crude oil was collected and analyzed. The result indicate that derivative contracts are $60 \%$ efficient in Price discovery. Irwin et al. (2009) examined data from commodity market and indicated that in the long-run equilibrium between spot and derivative market. He further concluded that cash market is strong in price discovery where actual forces of demand and supply effect price movement. 
. There are few studies in Indian context also. Easwaran and Ramasundaram (2008) concluded that derivative and spot agriculture commodities market are not integrated. Biswat Pratap Chandra (2008) conducted study to find out relationship between spot and derivative and inferred that long run cointegration exist between spot and derivative market.

Price discovery is one of the main functions of derivative trading. Price discovery is a process where price of underlying is determined through demand and supply forces created by various participants like hedger, speculators and arbitragers. In a dynamic market, price discovery is a continuous process. In commodity market several information influences the price discovery like demand and supply, weather forecast, Government policies etc. Market is said to be efficient in price discovery if there is proper convergence between the derivative and spot market.

Most of the studies conducted on relationship between spot market and derivative market are not in Indian context as Indian commodity market does not have long history. This papers attempts to study the relationship between spot and two different maturity derivative contracts of cardamom contracts trading MCX.

\section{OBJECTIVES OF STUDY}

1. To examine long term dynamics and short term dynamics of near month derivative contract and spot price of cardamom.

2. To examine long term dynamics and short term dynamics of spot and near month derivative contract

3. To examine long term dynamics and short term dynamics of next derivative contract and spot price of cardamom

4. To examine long term dynamics and short term dynamics of spot and next contract of derivative cardamom

\section{RESEARCH METHODOLOGY}

Two different maturity contracts, near month and next contract of derivative cardamom are studied. Near month contract is which have immediate expiry. Next contract is which expire after near month contract. The closing price for the derivative cardamom near contract and next contract was collected from MCX. Data for the spot price was also collected from MCX. Data was collected from January 2010 to June 2019. Further the data of spot price series and derivative price series was date wise reconciled. The markets are in convergence when co- integration between two markets is established.

To find out relationship between spot market and derivative market ARDL test is applied. Convergence or long term dynamics between the two markets were examined through ARDL Bound test. To find out short term dynamics between spot and derivative markets error correction methods was employed. Augmented Dickey-Fuller Test (ADF test) is employed to examine stationarity of the series.

\section{A. Augmented Dickey-Fuller Test}

ADF Test is used to check stationarity of spot and derivative price series of cardamom contract Testing procedure for ADF is as follows:

$\Delta \mathrm{X}_{\mathrm{t}}=\alpha+\beta \mathrm{t}+\Upsilon \mathrm{X}_{\mathrm{t}-1}+\delta \Delta \mathrm{X}_{\mathrm{t}-1}+\ldots \ldots \ldots \ldots . .+\delta_{\mathrm{p}-1} \Delta \mathrm{X}_{\mathrm{t}-\mathrm{p}+1}+\varepsilon_{\mathrm{t}}(1)$ In above $\alpha$ is intercept and $\beta$ is trend and $p$ is lag length. The dickey fuller test is done on intercept, intercept $\&$ trend and no trend and no intercept. For determining optimum lag length Akaike Information Criterion (AIC) test is used.

\section{B. ARDL Test}

ARDL model uses the lags of the dependent variablesand independent variables

$$
\begin{gathered}
\mathrm{SC}_{\mathrm{t}}=\mathrm{a}_{0}+\mathrm{a}_{1} \mathrm{SC}_{\mathrm{t}-1}+\ldots+\mathrm{a}_{\mathrm{p}} \mathrm{SC}_{\mathrm{t}-\mathrm{p}}+\mathrm{B}_{0} \mathrm{FC}_{\mathrm{t}}+\mathrm{B}_{1} \mathrm{FC}_{\mathrm{t}-1}+\ldots+ \\
\quad \mathrm{B}_{\mathrm{k}} \mathrm{FC}_{\mathrm{t}-\mathrm{k}}+\mathrm{e}_{\mathrm{t}}
\end{gathered}
$$

Spot cardamom (SC) is dependent variable with its $\mathrm{p}$ lags and $\mathrm{k}$ lags of independent variable derivative cardamom(FC).

\section{Long term Relationship}

Long term relationship between spot and derivative cardamom can be found out through ARDL bound test as per below equation.

$\Delta \mathrm{SC}_{\mathrm{t}}=\beta_{0}+\Sigma \beta_{\mathrm{i}} \Delta \mathrm{SC}_{\mathrm{t}-\mathrm{i}}+\Sigma \delta_{\mathrm{k}} \Delta \mathrm{FC}_{\mathrm{t}-\mathrm{k}}+\theta_{0} \mathrm{SC}_{\mathrm{t}-1}+\theta_{1} \mathrm{FC}_{\mathrm{t}-1}+\mathrm{e}_{\mathrm{t}}$

where $\Delta$ is the first difference operator and $\varepsilon$ is the white noise term. Optimum lag length was selected through the Akaike Information Criterion (AIC). The bound testing is based on the joint F-statistic or Wald statistic to test the null hypothesis of no cointegration between spot and derivative contract of cardamom. The null hypothesis of no cointegration among the variables in Eq. (2) is $\mathrm{H}_{0}: \theta_{0}=\theta_{1}=0$ against the alternative hypothesis $\mathrm{H}_{1}: \theta_{0} \neq \theta_{1} \neq 0$. ARDL bound test provides long term relationship or cointegration relationship between dependent and independent variable. If $\mathrm{f}$ value is above upper bound then it is proved that cointegation exist between dependent and independent variable. If $F$ value is below lower bound then cointegration does not exist between dependent and independent variables. If $F$ value falls between lower bound and upper bound then it is spurious regression

\section{Short run relationship}

$$
\begin{aligned}
& \Delta \mathrm{SC}_{\mathrm{T}}=\mathrm{B}_{0}+\Sigma \mathrm{B}_{\mathrm{I}} \Delta \mathrm{SC}_{\mathrm{T}-\mathrm{I}}+\Sigma \Delta_{\mathrm{K}} \Delta \mathrm{FC}_{\mathrm{T}-\mathrm{K}}+\Theta_{0} \mathrm{SC}_{\mathrm{T}-1}+\Theta_{1} \mathrm{FC}_{\mathrm{T}-1}+\Xi \\
& \mathrm{ECM}_{\mathrm{T}-1}+\mathrm{E}_{\mathrm{T}} \quad(4)
\end{aligned}
$$

Where residuals $e_{t}$ is independently and normally distributed with zero mean and constant variance and $\mathrm{ECM}_{\mathrm{t}-1}$ is the error correction term. $\xi$ is a parameter that indicates the speed of adjustment to the equilibrium level after a shock. It shows how quickly variables converge to equilibrium. Error correction term must have a statistically significant coefficient with a negative sign. 


\section{ANAlysis OF DATA AND FINDING}

\section{A. Augmented Dickey-Fuller Test(ADF Test)}

To check stationarity of the series ADF is applied and T-Statistic (T.S) at intercept( In), Trend and Intercept (T $\&$ In) and No intercept and Trend (None) along with $\mathrm{P}$ Value (PV) are tabulated in Table 1

TABLE I Results of 'unit root test

\begin{tabular}{|c|c|c|c|}
\hline & In & T \& In & None \\
\hline \multicolumn{4}{|c|}{ Spot } \\
\hline T.S & 0.93778 & 0.547283 & 1.351316 \\
\hline PV & 0.9960 & 0.9994 & 0.9561 \\
\hline T.S & -8.781579 & -9.007814 & -8.712509 \\
\hline PV & 0 & 0 & 0 \\
\hline \multicolumn{4}{|c|}{ Derivative } \\
\hline T.S & -0.454282 & -0.691383 & 0.747264 \\
\hline PV & 0.8974 & 0.9728 & 0.8756 \\
\hline T.S & -6.116105 & -6.323117 & -6.060977 \\
\hline PV & 0 & 0 & 0 \\
\hline \multicolumn{4}{|c|}{ Derivative Nest Contract } \\
\hline T.S & --1.840990 & -2.049141 & 0.204713 \\
\hline PV & 0.3608 & 0.5734 & 0.7457 \\
\hline T.S & -6.738449 & -6.872239 & -6.705044 \\
\hline PV & 0 & 0 & 0 \\
\hline
\end{tabular}

All the spot price series of cardamom is $1^{\text {st }}$ difference stationary at 5\% significance level. Derivative near month and next contract price series of cardamom is $1^{\text {st }}$ difference stationary at 5\% significance level. So ARDL can be applied.

\section{B. Cointegration and long term relationship between derivative near month and spot}

F-Statistic (F-S) Value (Val.) of cointegration relationship between derivative and spot price series of cardamom along with relevant significance level (SL) are tabulated in Table 2

TABLE 2

\begin{tabular}{|l|l|l|l|l|}
\hline $\begin{array}{l}\text { Test } \\
\text { Statistic }\end{array}$ & Val. & SL & $\mathbf{I}(\mathbf{0})$ & $\mathbf{I}(\mathbf{1})$ \\
\hline F-S & 15.64716 & $10 \%$ & 3.02 & 3.51 \\
\hline & & $5 \%$ & 3.62 & 4.16 \\
\hline & & $2.5 \%$ & 4.18 & 4.79 \\
\hline & & $1 \%$ & 4.94 & 5.58 \\
\hline
\end{tabular}

Maximum 8 lags of derivative near month and 8 lags of spot were found significant. ARDL The F value 14.76336 is above the upper bound which depicts that long term relationship exists between the series.

\section{Short term relationship between derivative near month and spot}

To find out short term relationship and speed of adjustment ECM is applied and results of ECM Coefficient (Cof.), Standard error (SE) T-statistic (TS) and P-value (PV)are tabulated below in Table 3

\begin{tabular}{|c|c|c|c|c|}
\hline Variable & Cof. & SE & TS & PV \\
\hline & & & & \\
\hline $\begin{array}{l}\text { D(DERIVA } \\
\text { TIVE }(-1))\end{array}$ & -0.064260 & 0.020512 & -3.132830 & 0.0018 \\
\hline $\begin{array}{l}\text { D(DERIVA } \\
\text { TIVE }(-2))\end{array}$ & -0.025531 & 0.020473 & -1.247060 & 0.2125 \\
\hline $\begin{array}{l}\text { D(DERIVA } \\
\text { TIVE }(-3))\end{array}$ & -0.025868 & 0.020337 & -1.271969 & 0.2035 \\
\hline $\begin{array}{l}\text { D(DERIVA } \\
\text { TIVE(-4)) }\end{array}$ & -0.054031 & 0.020239 & -2.669654 & 0.0076 \\
\hline $\begin{array}{l}\text { D(DERIVA } \\
\text { TIVE(-5)) }\end{array}$ & -0.036112 & 0.020182 & -1.789325 & 0.0737 \\
\hline $\begin{array}{l}\text { D(DERIVA } \\
\text { TIVE(-6)) }\end{array}$ & -0.022761 & 0.020229 & -1.125156 & 0.2606 \\
\hline $\begin{array}{l}\text { D(DERIVA } \\
\text { TIVE(-7)) }\end{array}$ & -0.058766 & 0.020078 & -2.926833 & 0.0035 \\
\hline $\mathrm{D}$ (SPOT) & 0.559481 & 0.032181 & 17.38544 & 0.0000 \\
\hline $\begin{array}{l}\text { D(SPOT(-1) } \\
\text { ) }\end{array}$ & 0.070871 & 0.033993 & 2.084891 & 0.0372 \\
\hline $\begin{array}{l}\mathrm{D}(\mathrm{SPOT}(-2) \\
)\end{array}$ & 0.012037 & 0.034077 & 0.353246 & 0.7239 \\
\hline $\begin{array}{l}\mathrm{D}(\mathrm{SPOT}(-3) \\
)\end{array}$ & 0.098587 & 0.034211 & 2.881704 & 0.0040 \\
\hline $\begin{array}{l}\mathrm{D}(\mathrm{SPOT}(-4) \\
)\end{array}$ & 0.047295 & 0.034408 & 1.374522 & 0.1694 \\
\hline $\begin{array}{l}\mathrm{D}(\mathrm{SPOT}(-5) \\
)\end{array}$ & 0.095489 & 0.034511 & 2.766888 & 0.0057 \\
\hline $\begin{array}{l}\mathrm{D}(\mathrm{SPOT}(-6) \\
)\end{array}$ & 0.035487 & 0.034595 & 1.025795 & 0.3051 \\
\hline $\begin{array}{l}\mathrm{D}(\mathrm{SPOT}(-7) \\
\text { ) }\end{array}$ & 0.132328 & 0.034251 & 3.863520 & 0.0001 \\
\hline $\begin{array}{l}\text { CointEq(-1) } \\
*\end{array}$ & -0.060885 & 0.008883 & -6.854063 & 0.0000 \\
\hline
\end{tabular}

R Squared : 0.147384 Adjusted R-squared: 0.142389 AIC Value: 9.812509

Error correction term -0.060885 is negative and significant which shows that short term relationship exist between the future near month and spot price series of cardamom. Speed of adjustment towards long run is $6.27 \%$.

\section{Cointegration and long term relationship between spot} and derivative near month

Results of cointegration between spot and derivative near month are reported in Table 4 
TABLE 4

\begin{tabular}{|l|l|l|l|l|}
\hline $\begin{array}{l}\text { Test } \\
\text { Statistic }\end{array}$ & Val. & SL & I(0) & I(1) \\
\hline F-S & 20.42099 & $10 \%$ & 3.02 & 3.51 \\
\hline & & $5 \%$ & 3.62 & 4.16 \\
\hline & & $2.5 \%$ & 4.18 & 4.79 \\
\hline & & $1 \%$ & 4.94 & 5.58 \\
\hline
\end{tabular}

8 lags of spot and 2 lags of derivative near month were significant as this combination was having lowest AIC value. F value 20.42099 is above than upper bound value which shows that long run relationship exist.

\section{E. Short run relationship between spot and derivative near month}

Results of ECM to find out relationship between spot and derivative are tabulate below in Table 5

TABLE 5

\begin{tabular}{|l|c|l|l|l|}
\hline Variable & Cof. & SE & TS & PV \\
\hline & & & & \\
\hline & & & & \\
\hline D(SPOT(-1)) & 0.099357 & 0.019353 & 5.134044 & 0.0000 \\
\hline D(SPOT(-2)) & 0.042385 & 0.018680 & 2.269049 & 0.0233 \\
\hline D(SPOT(-3)) & 0.007790 & 0.018790 & 0.414588 & 0.6785 \\
\hline D(SPOT(-4)) & 0.084372 & 0.018779 & 4.492967 & 0.0000 \\
\hline D(SPOT(-5)) & 0.007472 & 0.018885 & 0.395672 & 0.6924 \\
\hline D(SPOT(-6)) & 0.007737 & 0.018889 & 0.409615 & 0.6821 \\
\hline D(SPOT(-7)) & -0.062168 & 0.018933 & -3.283562 & 0.0010 \\
\hline $\begin{array}{l}\text { D(DERIVATI } \\
\text { VE) }\end{array}$ & 0.188869 & 0.010802 & 17.48457 & 0.0000 \\
\hline $\begin{array}{l}\text { D(DERIVATI } \\
\text { VE(-1)) }\end{array}$ & 0.056050 & 0.011466 & 4.888278 & 0.0000 \\
\hline CointEq(-1)* & -0.030311 & 0.003871 & -7.830118 & 0.0000 \\
\hline
\end{tabular}

R Squared : 0.171093 Adjusted R squared: 0.168185 AIC Value: 8.722988

Error correction term -0.030311 is negative and significant which signifies that short term relationship exist between the spot and near month derivative of cardamom. The speed of adjustment towards long run is $3.03 \%$.

\section{F. Cointegration and Long term relationship between derivative next contract and spot}

TABLE 6

\begin{tabular}{|l|l|l|l|l|}
\hline $\begin{array}{l}\text { Test } \\
\text { Statistic }\end{array}$ & Val. & SL & I(0) & I(1) \\
\hline F-S & 6.135819 & $10 \%$ & 3.02 & 3.51 \\
\hline & & $5 \%$ & 3.62 & 4.16 \\
\hline & & $2.5 \%$ & 4.18 & 4.79 \\
\hline & & $1 \%$ & 4.94 & 5.58 \\
\hline
\end{tabular}

7 lags of derivative next contract and 7 lags of spot cardamom were found significant. F value 7.029846 is above the upper bound value which proves that long term relationship exist between the derivative next contract and spot price series of cardamom.
G. Short term relationship between derivative next contract and spot

TABLE 7

\begin{tabular}{|c|c|c|c|c|}
\hline Variable & Cof. & SE & TS & PV \\
\hline & & & & \\
\hline D(DERIVATI & -0.00665 & & & \\
\hline VENM(-1)) & 6 & 0.020039 & -0.332153 & 0.7398 \\
\hline D(DERIVATI & -0.05695 & & & \\
\hline VENM(-2)) & 7 & 0.020059 & -2.839434 & 0.0046 \\
\hline D(DERIVATI & -0.01752 & & & \\
\hline $\operatorname{VENM}(-3))$ & 9 & 0.020109 & -0.871681 & 0.3835 \\
\hline D(DERIVATI & -0.00710 & & & \\
\hline VENM(-4)) & 2 & 0.020117 & -0.353017 & 0.7241 \\
\hline D(DERIVATI & 0.01835 & & & \\
\hline VENM(-5)) & 3 & 0.020082 & 0.913869 & 0.3609 \\
\hline D(DERIVATI & -0.07481 & & & \\
\hline $\operatorname{VENM}(-6))$ & 8 & 0.020115 & -3.719458 & 0.0002 \\
\hline & 0.47914 & & & \\
\hline $\mathrm{D}(\mathrm{SPOT})$ & 1 & 0.022740 & 21.07003 & 0.0000 \\
\hline D(SPOT(-1)) & $\begin{array}{r}-0.03876 \\
8 \\
\end{array}$ & 0.024521 & -1.581039 & 0.1140 \\
\hline $\mathrm{D}($ SPOT(-2)) & $\begin{array}{r}0.08935 \\
8 \\
\end{array}$ & 0.024617 & 3.629876 & 0.0003 \\
\hline D(SPOT(-3)) & $\begin{array}{r}0.04728 \\
3 \\
\end{array}$ & 0.024742 & 1.911076 & \\
\hline $\mathrm{D}(\operatorname{SPOT}(-4))$ & $\begin{array}{r}0.01997 \\
6 \\
\end{array}$ & 0.024844 & 0.804059 & 0.4214 \\
\hline D(SPOT(-5)) & $\begin{array}{r}0.05103 \\
6 \\
\end{array}$ & 0.024841 & 2.054557 & 0.0400 \\
\hline D(SPOT(-6)) & $\begin{array}{r}0.09113 \\
6 \\
\end{array}$ & 0.024286 & 3.752679 & 0.0002 \\
\hline CointEq(-1)* & $\begin{array}{r}-0.01787 \\
7 \\
\end{array}$ & 0.004165 & -4.292066 & 0.0000 \\
\hline
\end{tabular}

R Squared : 0.176796 Adjusted R-squared: 0.172620 AIC Value: 9.105082

Error correction term -0.017877 is negative and significant which implies that short term relationship exist between next contract derivative and spot price series of cardamom and speed of adjustment towards long run is $1.78 \%$.

H. Cointegration and long term relationship between spot and derivative next contract

TABLE 8

\begin{tabular}{|l|l|l|l|l|}
\hline $\begin{array}{l}\text { Test } \\
\text { Statistic }\end{array}$ & Val. & SL & $\mathbf{I}(\mathbf{0})$ & $\mathbf{I}(\mathbf{1})$ \\
\hline F-S & 13.50868 & $10 \%$ & 3.02 & 3.51 \\
\hline & & $5 \%$ & 3.62 & 4.16 \\
\hline & & $2.5 \%$ & 4.18 & 4.79 \\
\hline & & $1 \%$ & 4.94 & 5.58 \\
\hline
\end{tabular}


5 lags of spot and 8 lags of derivative next contract of cardamom were found significant. F value 19.00073 is above the upper bound value so long term relationship exist between spot price series of cardamom and next contract derivative prices of cardamom.

I. Short term relationship between spot and derivative next contract

TABLE 9

\begin{tabular}{|c|c|c|c|c|}
\hline Variable & Cof. & SE & TS & PV \\
\hline Variable & $\begin{array}{l}\text { Coefficien } \\
\mathrm{t}\end{array}$ & Std. Error & $\mathrm{t}$-Statistic & $\begin{array}{l}\text { Pro } \\
\text { b. }\end{array}$ \\
\hline $\mathrm{D}(\operatorname{SPOT}(-1))$ & 0.094343 & 0.019508 & 4.836165 & $\begin{array}{r}0.00 \\
00 \\
\end{array}$ \\
\hline $\mathrm{D}(\mathrm{SPOT}(-2))$ & 0.037995 & 0.019718 & 1.926927 & $\begin{array}{r}0.05 \\
41\end{array}$ \\
\hline $\mathrm{D}(\operatorname{SPOT}(-3))$ & 0.013119 & 0.019829 & 0.661591 & $\begin{array}{r}0.50 \\
83\end{array}$ \\
\hline $\mathrm{D}(\operatorname{SPOT}(-4))$ & 0.067193 & 0.019751 & 3.401931 & $\begin{array}{r}0.00 \\
07\end{array}$ \\
\hline $\begin{array}{l}\text { D(DERIVATI } \\
\text { VENM) }\end{array}$ & 0.304901 & 0.014540 & 20.96942 & $\begin{array}{r}0.00 \\
00\end{array}$ \\
\hline $\begin{array}{l}\text { D(DERIVATI } \\
\text { VENM(-1)) }\end{array}$ & 0.114788 & 0.015892 & 7.223003 & $\begin{array}{r}0.00 \\
00\end{array}$ \\
\hline $\begin{array}{l}\text { D(DERIVATI } \\
\text { VENM(-2)) }\end{array}$ & -0.014387 & 0.016058 & -0.895927 & $\begin{array}{r}0.37 \\
04\end{array}$ \\
\hline $\begin{array}{l}\text { D(DERIVATI } \\
\text { VENM(-3)) }\end{array}$ & -0.036390 & 0.016029 & -2.270257 & $\begin{array}{r}0.02 \\
33 \\
\end{array}$ \\
\hline $\begin{array}{l}\text { D(DERIVATI } \\
\text { VENM(-4)) }\end{array}$ & 0.021038 & 0.016059 & 1.310076 & $\begin{array}{r}0.19 \\
03\end{array}$ \\
\hline $\begin{array}{l}\text { D(DERIVATI } \\
\text { VENM(-5)) }\end{array}$ & -0.028090 & 0.014990 & -1.873876 & $\begin{array}{r}0.06 \\
11\end{array}$ \\
\hline $\begin{array}{l}\text { D(DERIVATI } \\
\text { VENM(-6)) }\end{array}$ & 0.023724 & 0.014674 & 1.616733 & $\begin{array}{r}0.10 \\
61 \\
\end{array}$ \\
\hline $\begin{array}{l}\text { D(DERIVATI } \\
\text { VENM(-7)) }\end{array}$ & -0.048149 & 0.014664 & -3.283459 & $\begin{array}{r}0.00 \\
10 \\
\end{array}$ \\
\hline CointEq(-1)* & -0.015271 & 0.002398 & -6.368493 & $\begin{array}{r}0.00 \\
00\end{array}$ \\
\hline
\end{tabular}

\section{$R$ Squared : 0.225949 Adjusted R-squared: 0.222325 AIC Value: 8.656847}

Error correction term -0.015271 is negative and significant so short run relationship between spot and next contract derivative prices of cardamom. The speed of adjustment towards long run is $1.52 \%$.

\section{Conclusion}

The long term relationship or co-integration exists between near month derivative price and spot price series of cardamom. Long term relationship also exists between next month derivative price series of cardamom and spot price of cardamom. Co-integrations also exist between spot and near month derivative price series of cardamom. Long term relationship is also found between spot and next contract derivative series of cardamom. Short term relationship was found in near month derivative price series of cardamom and spot price series of cardamom and vice versa also. Short term relationship was found in next contract derivative price series of cardamom and spot price series of cardamom and vice versa also. The speed of adjustment towards long term is more in near month contract than next derivative contract. So the derivative contract of cardamom is efficient as long term and short term dynamics exists between the spot and derivative. Near month contracts are more efficient then next contract of derivative as speed of adjustment is higher in near month contract.

\section{REFERENCES}

1. F. Lake, "The Miller's use of the commodity exchange" In A. Peck (ed). Views from the trade (Chicago: Board of Trade of the City of Chicago, 1978

2. G.Bekaert, C.R. Harvey, and , C. Lundblad, "Liquidity and expected returns: lessons from emerging markets," Review of Financial Studies, vol. 20, pp.1783-1831, 2007

3. H.R. Stoll, and R.E. Whaley, "The Dynamics of Stock Index and Stock Index Futures Returns," Journal of Financial and Quantitative Analysis, vol. 25(4) pp. 441-468,1990

4. I. Kawaller, P. Koch, and J. Peterson, "Volume and volatility surrounding quarterly redesignation of the lead S\&P 500 futures contract" Journal of Future Markets, vol.21(12), pp.1119-1149, 2001

5. J. Yang, and J.D. Leatham, , "Price Discovery In Wheat Futures Markets," Journal of Agricultural and Applied Economics, Southern Agricultural Economics Association, vol. 31(2), pp 1-12, 1999

6. K. Garbade and W.L. Silber,'Price movements and price discovery in futures and cash markets," The Review of Economics and Statistics, vol. 65(2), pp. 289-97,1983

7. P.C. Biswal, "Price Discovery in Futures and Spot Commodity Markets in India,” Al-Barkaat Journal of Finance \& Management, pp. 21-44, 2008

8. P. Silvapulle, and I.A. Moosa, "The relationship between spot and future prices: evidence from the crude oil market," J. Futur. Mark., vol.19, pp175-193,1999

9. R.F. Engle, and W. J. Granger," Co-Integration and Error Correction: Representation, Estimation, and Testing," Econometrica,vol. 55(2), pp. 251-276, 1987

10. R. Salvadi Easwaran and P. Ramasundaram, "Whether Commodity Futures Market in Agriculture is Efficient in Price Discovery?-An Econometric Analysis" Agricultural Economics Research Review, Vol. 21, pp 337-344, 2008

11. S. Beck, , "Co integration and market efficiency in commodities futures markets," Appl.Econ. , Vol. 26, pp. 249-257,1994

12. S. Irwin, "A speculative bubble in commodity futures prices? Cross-sectional evidence" Agricultural Economics, vol. 41(1),pp. 25-32,2010

13. T. Schwarz, and A. Szakmary, "Price discovery in petroleum markets: arbitrage, cointegration and the time interval of analysis," Journal of Futures Markets, vol.14(2), pp. 147-167, 1994

14. V. Wiese, "Use of commodity exchanges by local grain marketing organizations" In A. Peck (ed).Views from the trade(Chicago: Board of Trade of the City of Chicago, 1978

\section{AUTHORS PROFILE}

Sachin Kumar , P.G Depatment of Commerce, S.D.College, Hoshiarpur,India, Sachinkatira@yahoo.com

Yash Pal Taneja, P.GDepartment of Commerce \& Management G.G.D.S.D College, Chandigahr, India, Dryash.pal@gmail.com

Nishi Bala, Deparment of Commerce and Management Ludhiana Group of Colleges, Ludhiana, India, Nishibala2009@rediffmail.com 